\title{
Local Leader Election According to Acts No. 9, 2015 as Related to Local Government System Found in Pancasila and the 1945 Constitution of the Republic of Indonesia
}

\author{
Muhammad Ar. Husein ${ }^{1} \quad$ J. Ronald Mawuntu ${ }^{2} \quad$ Wulanmas A. P. G. Frederik ${ }^{2} \quad$ Tommy Sumakul $^{3}$ \\ 1.PhD Student, Departement of Law Studies, Postgraduate Program, Sam Ratulangi University, Manado, \\ Sulawesi Utara, Indonesia \\ 2.Profesor Departement of Law Studies, Postgraduate Program, Sam Ratulangi University, Manado, Sulawesi \\ Utara, Indonesia \\ 3.Departement of Law Studies, Postgraduate Program, Sam Ratulangi University, Manado, Sulawesi Utara, \\ Indonesia
}

\begin{abstract}
The research is financed by Postgraduate Programe, Departement of Law, Sam Ratulangi University, Indonesia Abstract

According to the constitution, local leaders election is people's sovereignty right, whether it is direct or indirect. This right is implemented by electing the local leaders once in five years in the realization of local leader election as a system in Indonesia. The fourth principle of Pancasila states that "democracy is led by prudence and wisdom in the deliberation of delegation" and Chapter 18 verse 4 states that "Governor, Regent, and Mayor as the heads of local government in a province, regency, and city should be elected democratically," which is associated with Acts No. 23, 2014 "about local government" in which Chapter 1, verse (6) states that "Local Autonomy is a right, and it is local autonomy's responsibility to manage and administer individually its government and local society's interest in the system of the Unitary State of the Republic of Indonesia." Verse (7) states "Autonomy Principle is the basic principle of the implementation of local government based on local autonomy." Government's Regulation No. 1, 2014 states about the election of governor, regent, and mayor; and Chapter 1, verse (23) states that "Local Government is the Governor, Regent, Mayor, and the local officers as the organizational element of the local government."
\end{abstract}

Keywords: Local Leader Election, Local Government, Local Autonomy, Pancasila, the 1945 Constitution of the Republic of Indonesia.

DOI: $10.7176 /$ PPAR/9-3-08

Publication date:March $31^{\text {st }} 2019$

\section{A. Background of the Study.}

General elections of the local leaders and their vices which are usually implemented once in 5 (five) years, whether it is in a province, regency, or city always cause problem and this also leads to opinion differences in the society. There are some parties requiring the local leader election to be implemented indirectly while the rests want it to be implemented directly. Acts No. 9, 2015 related to "local government" 1 chapter 62 gives the hint which is stated that local leader election is managed by Acts No. 22, 2014 respecting indirect local leader election, Acts No: 10, 2016 which is referred to the second change of Acts No 1, 2015 related to the fulfillment of government regulation as the substitute of Acts No. 1, 2014 regarding the "election of governor, regent, and mayor has become the Acts" 2 is a breakthrough effort of democratization which is started for the first time by applying direct election in June 2005 when SBY was elected as President who was chosen directly by the citizens. The second direct election was implemented in 2009, and SBY was once again elected as the President, but when it came to the end of reigning period (2014) when ${ }^{3}$ (Indonesian Legislatives) which consists of: House of People's Representatives (DPR), Regional Representative Council (DPD), and Assembly at Provincial/Regional (DPRD) which were elected directly by people, and also after the Republic of Indonesia's seventh president (Joko Widodo) was inaugurated, House of People's Representative (DPR) managed to have plenary meeting for three days, which was conducted on September 28 to September 30, 2014. This meeting discussed about the design of the Acts of regional or local leaders election and their vices. The first second days of the meeting, there was still no agreement yet, and then voting has been implemented by the two coalitions of the House of People's Representative (DPR) to gain the final agreement. The first coalition is called Great Indonesian Coalition "Koalisi Indonesia Hebat" (KIH), and the other one is called Red and White Coalition "Koalisi Merah Putih" (KMP). The result of the voting showed that Red and White Coalition dominated the votes and it concluded that local leader election and their vices would be conducted indirectly. It means the election would be implemented by Assembly at Provincial/Regional (DPRD). This result showed that many of

'UU No : 23 Tahun 2014 Tentang "Pemerintahan Daerah"

${ }^{2}$ PERPPU No : 1 Tahun 2014 "Tentang Pemilihan Umum Secara Langsung.

${ }^{3}$ Posko Malut 30 September 2014 hal 1, 15 
House of People's Representative's members do not want the local leaders and their vices election to be done directly. It means the result has been suitable with the 1945 Constitution of Republic of Indonesia and Acts No. 23, 2014 regarding the election of Governor, Regent, and Mayor. It is stated that "the election of governor, regent, and mayor is continuously to be called election, is an executor of people's sovereignty in province, regency, and city to elect governor, regent, and mayor democratically trough the council of people's representatives." 1

According to ${ }^{2}$ Carl Freidrich in Titik Wulan Tutik, SH.,MH "the principals of Indonesia's constitutional law after amendment of the 1945 constitution of Republic of Indonesia states that "General election is assumed to express the representatives of people's aspirations which are strongly related to government's legitimacy. Sovereignty means that people have the highest authority. People have rights to design the management of governmental administration and the reigning process, and people also have rights to decide the aims which are wanted to be achieved. Next, it is stated that if "a country which consist of small amount of citizens while the area is not that large, people's sovereignty cannot be implemented purely and righteously, especially in modern country where its population is big and the area is large enough, it is impossible to ask people's opinion one by one when it comes to the decision of managing the governmental issues. This case happens because modern people have more keen specialization and have various intelligence levels. This causes people's sovereignty might not be implemented righteously. That is why people's sovereignty needs to be managed by people's representative assembly"3

The highest Indonesian constitutions are Pancasila and the 1945 Constitution of Republic of Indonesia while the fourth principle of Pancasila states that "democracy is led by prudence and wisdom in its deliberation". The 1945 Constitution of Republic of Indonesia, Chapter 18, verse (4) states that "governor, regent, and mayor, are each the head of province, regency, and city who are elected democratically." When we refer to the word "democracy", democracy means involving people who fulfill the requirements completely, while the word "democracy" also is the last value of democracy which means, after the general election has been done, the election that has been done democratically will not cause any problem. This truly means democracy.

H. Alwi Wahyudi argues in his book entitled "Hukum Tata Negara Indonesia dalam Perspektif Pancasila Pasca Reformasi" 2012 that "by not changing the preamble of the 1945 Constitution of Republic of Indonesia, then the position of Pancasila will not be changed at all as the main source of legal material and as foundation of philosophy of United Republic of Indonesia." Alwi then adds that there are several reasons related to Pancasila as the highest legal source in Indonesia's constitutional system. The reasons are:

a). Pancasila is the content of legal source.

b). Pancasila is country's vision and philosophy.

c). Pancasila is the "spirit" of the nation. Every rule which is made and implied by the Acts, or any law which is contradicted with the spirit of Pancasila should be removed or being proclaimed as illegal. ${ }^{4}$

The direct election which involves the people is actually opposed the spirit of Pancasila, because direct election involving people is just for legislative assembly such as House of People Representatives (DPR), Regional Representative Council (DPD), and Assembly at Provincial, Regency, or City (DPRD) because they are the people's representatives. According to chapter 18 verse (3) of the 1945 Constitution of Republic of Indonesia;" "Government of the province, regency, and city has representatives which are elected by general election." This statement is linked to the chapter 19 verse (1) which states that "the members of people's representatives who are elected by general election will be the ones who are going to choose governor, regent, and mayor." This is instruction of our highest constitution. Chapter 18 verse (4) of the 1945 Constitution of Republic of Indonesia states that "governor, regent, and mayor as each the head of province, regency, and city, would be chosen democratically."

The case above is associated with the philosophical meaning of the fourth principle of Pancasila because democratic election does not always mean that direct election should be implemented, because direct election does not always be true democracy. But if indirect election is implemented democratically (according to the majority of the votes, and it does not cause any political problem, even if there is dishonesty being applied, it might be caught easily due to small amount of people's representative members who do the voting, and as result, the majority who vote in indirect election, successfully elect the governor, regent, and mayor ${ }^{6}$ although trough the Assembly at Regional, President SBY was not willing to sign that Acts by claiming that it was the worst political drama. Senior Researcher of Indonesia Public Institute named Karyono Wibowo ${ }^{7}$ when he attended the

\footnotetext{
${ }^{1}$ Lihat pasal 1 ayat (5).UU No. 22 Tahun 2014, tentang Pemilihan Gubernur, Bupati dan Walikota

${ }^{2}$ Titik Triwuln Tutik 2008, Pokok-Pokok Hukum Tata Negra Indonesia pascaamandemen UUD 1945. hal. 379-380

${ }^{3}$ Titik Wulan Tutik 2008. Ibid hal 380

${ }^{4}$ H.Alwi Wahyudi, 2012, Hukum Tata Negara Indonesi dalam Perspektif Pancasila Pasca Reformasi,hal 126.

${ }^{5}$ Bunyi pasal 18, 19 UUD 1945

${ }^{6}$ Fajar Malut 30 September 2014 hal. 1, 11

${ }^{7}$ Karyono Wibowo, Peneliti Senyior, menghadiri diskusi Taman Ismail Marzuki Fajar Malut,30 September 2014 hal 1, 11.
} 
discussion forum in Ismail Marzuki Cikini Park in central Jakarta on September 28, 2014 said that "Susilo BambangYudoyono's (SBY) attitude is a series of his drama after plenary session on September 28 to September 30, 2014. It was actually the worst political drama. The first one was when the members of Democratic Party in the first place supported the Acts and after a while, they rejected it. The second one was when the members of Democratic Party decided to walk out (WO) from the meeting room. The third one was when SBY seemed to pretend that he disagreed with the attitude of other members of Democratic Party. It seemed that SBY did that intentionally to aim the reign of Joko Widodo and Jusuf Kalla, but by doing this, people were able to know more about the real SBY and Democratic Party. ${ }^{1}$

For gaining people's response, although it seemed to be funny, it is not appropriate for a president to force himself to accuse or criticize the Acts of general election which is already being legalized by the House of People's Representatives trough a long way and tiring process. Because of this issue, another scandal arose by stating that if people and the elites agree with SBY to accuse the Acts of general election, it means both of the parties do not respect the decision of the House of People's Representatives as the legal representatives of the Indonesians, and this case is contradicted with the 1945 Constitution of Republic of Indonesia. Therefore, if the election of governor, regent, and mayor might be done directly, then the fourth principle of Pancasila and chapter 18, verse (4) of the 1945 Constitution of Republic of Indonesia, and also chapter 20, verse (4) to verse (5) should be changed like the fourth principle of Pancasila needs to be changed by what kind of sentence? And also, chapter 18, verse (4), chapter 20 verse (4) to verse (5) should be amended first, but this case also leads to the argument that it is necessary to defend the image of the 1945 Constitution of Republic of Indonesia and defend Pancasila as well as the highest legal source, is actually an advance step which is suitable with the government's statement which states that "if we want to formulate a design or concept, it (should be agreeable with Pancasila and the 1945 Constitution of Republic of Indonesia) because indirect general election is actually agreeable with the constitution. Thus, if president (SBY) proposed to do material test to the constitutional court of Indonesia, Acts No. 22, 2014 related to the election of governor, regent, and mayor and even wanted to remove the Acts, it means, it is not (Government's Constitution as the Substitute of the Acts) but the indication of that Enactment of Government Regulation in Lieu of law is (Presidential Decree of the substitute of the Acts). By referring to constitutional law, presidents as the head of government should respect the decision of the House of People's Representatives because they belong to the government, and should not interfere as well as the representative and even as the chairman of Democratic Party. In fact, long time before the discussion of the Acts of indirect local leaders' election, members of Democratic Party had given their support to the Acts, but at the end of the process, the members of Democratic Party decided to walk out from the meeting room. This issue has been assumed as SBY's scenario, and also caused Democratic Party to have bad reputation. ${ }^{2}$ The vice chairman of legislation relation and executive of Golkar Party named Priyo Budi Santoso 3 said that "although Enactment of Government Regulation in Lieu of Law (PERPPU) that had been suggested by SBY related to the general election has been signed by the president himself, but the Enactment of Government Regulation in Lieu of Law (PERPPU) did not obtain the agreement of House of People's Representatives, and they would face Red and White Coalition as well, then that so called PERPPU would be rejected, while the Acts of general election that had been authorized by the House of People's Representatives in the plenary session on September 25, 2014 would be valid. ${ }^{4}$ Prof. Dr. Suwardi Lubis, said that "the election of local leaders (PILKADA) might save the state's budget for tens of trillions rupiahs, therefore this decision has been thought carefully related to the positive or negative effects of it. That is why Indonesian people should not be provoked by President SBY as the head of the government at that time. SBY's position as president succeeded to make the people support him because people presume that they have responsibility to control the government issue because they already chose the legislatives directly, therefore they want to be selective for choosing the people's representatives through direct election, whether they are the House of People's Representatives, the Regional Representative Council, and Assembly at Province or Region.

Based on the evaluation, the direct election of governor, regent, and mayor, automatically described the empirical fact which claimed that the nation's budget that needs to be spent for the candidates of governor/vice governor, regent/vice regent, and mayor/vice mayor for direct election will directly lead to the corruption, the decline of effectiveness of governmental implementation, the increase of escalation conflict and also the decline of voters' participation, and these things cause the country to spend so much budget. This case is suitable with the statement of Minister of Home Affairs (in SBY's period as President on 2nd season, Gamawan Fauzi) ${ }^{5}$ Fauzi

\footnotetext{
${ }^{1}$ Fajar Malut 29 September 2014 hal. 1, 11.

${ }^{2}$ Fajar Malut 30 September 2014 ibid. hal 1, 11

${ }^{3}$ Posko Malut 29 September 2014 Prio Budi Santoso, Ketua Legislasi dan Eksekutif Partai Golkar PERPPU yang diajukan SBY akan ditolak oleh Koalisi Merah Putih hal. 1.

${ }^{4}$ Posko Malut 29 September 2014 hal 2, 15.

${ }^{5}$ Gamawan Fauzi Menteri Dalam Negeri Jilid II masa Presiden SBY, dalam suatu saat mengatakan di TV One Pemilihan Umum secara langsung sudah tiga kali menghabiskan anggran triliunan rupiah, belum lagi PSU, Rakyat meninggal dunia kurang lebih 17 ribuh orang, fasilitas Negara/pribadi rusak tidak sedikit, terjadi renggangnya persaudaraan dimasyarakat yang cukup lama. Karena sentimentil pribadi,
} 
said in one event that "direct general election has been implemented for three times and already spent budget of hundreds of trillion rupiahs. Those who are already passed away are approximately 17.000 people, there are many of country's facilities have been broken or damaged. The budget for the repair might spend a big amount of money, it is still not included yet the personal facilities which are broken, and the most important thing is this direct election causes the breach of brotherhood and friendship because of personal sentiment between older and younger brother, between father and son, or even between neighbors who have different favorite candidate. This issue sometimes taken place for long period and often causes depression and the lost of peace among the members of the society.

${ }^{1}$ The president of Republic of Indonesia, Soesilo Bambang Yudoyono (SBY) officially issued 2 (two) Enactments of Government Regulation in Lieu of Law (PERPPU) related to the implementation of local leaders election. The first one is PERPPU No: 1, 2014 regarding the election of governor, regent, and mayor. This PERPPU automatically replaced Acts No: 22, 2014 regarding the election of governor, regent, and mayor. The second one is PERPPU No: 23, 2014 regarding the local government, where the content is about the authority abolishment of Assembly at Province/Region to implement local leaders' election, and SBY himself proclaims that "I sign this myself to prove that I join the society to elect the local leaders directly."

\section{B. Research Method}

This type of study is called socio-legal research (sociological legal research) or is categorized as descriptive study by using non doctrinal approach while viewing the law as observed socio-empirical indication and experience. Law is not conceptualized as an abstract norm and common normative issue. It is an empirical indication that could be observed through its implementation. In this study, the focus of the law is the issue of direct and indirect election as the right, authority, and responsibility in the implementation of general election to actualize public service, with a final aim to create an honest, pure, and fair and also without causing any problem. ${ }^{2}$

The assessment of this study is implemented in three layers of law science. They are dogmatic law, theory of the law, and philosophy of the law. The first is dogmatic law layer. It is aimed to study the description of the rule of law which organize the indirect general election of local leaders and direct general election of local leaders where the implementation has not been done properly yet. The second is the theory of law layer. It studies several theories of law which are associated with general election and its implementation. The last is the philosophy of law layer. It studies the meaning and the facts of indirect general election and also direct general election framework of regional or local autonomy.

\section{Data Analysis}

The data obtained from the field were analyzed qualitatively to be further described and analyzed using a theoretical basis with the aim of producing data or any indication of it. The data analysis techniques used in this study were calculation using frequency tabulation. ${ }^{3}$

\section{A. General Election System according to Acts No. 23, 2014.}

Chapter 18 of the 1945 Constitution of Republic of Indonesia already gave the hints for us that the United Country of Republic of Indonesia is divided into provinces, and provinces are divided into regions and cities which are located in each province. Each region or city has its own local government which is arranged by the Acts. (Chapter 18 verse (1) and verse (2) state that "local governments of province, region, and city manage and arrange their own governmental issues according to local autonomy principles and monitoring task." "Local governments of province, regency, and city have their own local representatives where the members are elected trough general election (chapter 18 verse (4) of the 1945 Constitution of Republic of Indonesia), governor, regent, and mayor are the heads of government for their own province, regency, and city are elected democratically. ${ }^{4}$ Chapter 19 verse (1) "the member of the House of People's Representatives is elected trough general election."

Acts No. 10, 2016 related to the second change of Acts No. 1 in 2015 which states about the Enactment of Government Regulation in Lieu of Law No : 1, 2014 regarding the election of governor, regent, and mayor had been the Acts chapter 7, verse (1) which is stated that: "every citizen has the right to have the same opportunity to be elected and nominated as the candidates of governor and his/her vice, regent and his/her vice, and also mayor and his/her vice" verse (2) "the candidates of governor and his/her vice, regent and his/her vice, and also

oleh karenanya, sebaiknya pemilihan umum kepala daerah dikembalikankepada DPR.

${ }^{1}$ Presiden SBY, mengeluarkan 2 buah PERPPU, No 1, tahun 2014, PERPPU No. 23 tahun 2014, tentang pemerintahan daearah yang isinya mencabut kewenangan pasal 3 ayat (1) dan ayat (2).

${ }^{2} \mathrm{Htt}$ //rulhome.blog.com/2010/4/11/contoh-metode-penelitian-normatif dengan-penelitian empiris/.

${ }^{3}$ I. Nyoman Nurjaya, ibid, hal, 128.

${ }^{4}$ Pasal 18 ayat 4 Undang-undang Dasar 1945. 
mayor and his/her vice as being arranged from the alphabetic order which is started from the letter a to the letter u. ${ }^{1}$

The implementation of local leader election is a part of the steps to actualize the democratic agenda as a whole, or as one commitment of democratic country which is already being outlined by the constitution. Democratic process in local area expects to elect local leaders who reflect the paradigm of nation's aspiration as the real sovereign holders. Indonesia tries hard to implement democracy as it is instructed by the constitution, where democracy is upheld by the democracy of Pancasila. One of democratic practice of Pancasila is general election which has been the momentum of leadership transition whether it is in central government, or local government which applies the value and the philosophy of Pancasila equivalence or being in line along with universal principles, democracy, and other freedom principles which are developed, along with justice enforcement, and human rights. Because of this reason, the democracy which is embraced by Indonesian is called Pancasila democracy which is democracy system that is balanced with the values of Pancasila as the foundation of the country and nation's view of life, which is suitable along the content of fourth principle of Pancasila "the democracy is led by prudence and wisdom in its deliberation."

It becomes our collective consensus as a nation and a sovereign state that every aspect of national development must be subject to Pancasila as the Ideal Foundation and the 1945 Constitution of Republic of Indonesia as the Constitutional Foundation, and the Archipelago's Insights as National Resilience is a Conceptual basis, which can be described as follows: ${ }^{2}$

As the views of life, Pancasila contains the knowledge of the essence, origin, purpose, and the meaning of the whole universe, especially the human beings and their lives, whether it is individual or social. The nation's philosophy of life reflects itself by collocating the human beings' balance and prestige as central factor in the life as a whole nation and country. By locating Pancasila as the core of life and even makes it as the foundation of every aspect of nation's life, Pancasila has been the dreams of Indonesian's morality that tie all people together, whether it is individual or as a whole nation.

It has been recognized that Pancasila is philosophy, idology, and foundation of the nation. As the life foundation of nation and country, Pancasila is the Ideal Foundation for the general election implementation, whether it is national or regional. MB. Zubakrum Tjenrang states that "the values and philosophy of Pancasila Equivalence is in line with the principles of universal democracy, which are continuous freedom principles, justice enforcement and human rights. That is why democracy that has been implemented by the Indonesian is Pancasila democracy. It is democracy system that has been aligned along with Pancasila's values as the country's foundation and the life view of the nation" 3

Although the 1945 Constitution of Republic of Indonesia has been amended for four times, it should practically be the strong constitutional foundation for every life aspect of the nation and country, because amendment does not mean to reduce the values and meaning of the 1945 Constitution of Republic of Indonesia that had been conducted by the Indonesian elders who were called Founding Fathers, but solely aimed to adjust itself with modernization era and nation's dynamic life. ${ }^{4}$

The 1945 Constitution of Republic Indonesia as a kind of well-known constitution in many literatures might derive its meaning in narrow or extensive way. By referring to narrow way, constitution is comprehended as legal documents only. However, when it is referring to extensive way, constitution does not only talk about (legal document) only, but also discuss about "non-legal aspects." The definition of Constitution in extensive way as mentioned by Bolingkroke is: quoted by K.C. Wheare "by constitutions, we meant whenever we speak with propriety and exactness, the assemblage of laws, institutions and customs, derived from certain fixed principles of reason, that compose the general system, according to which the community had to be governed" 5 . Based on the definition above, Bolingkroke claims that constitution is a form of rules of how several aspects would be the foundation for a country, whether it is legal aspect, or other aspects that have been derived from people's agreements. According to Balingkore, other aspects could be social aspects or philosophical aspects. The flexibility of constitutional dimension which is mentioned by Bolingkroke is actually associated with the static or dynamic meaning of constitution itself.

Constitution in its static meaning is related to its form as constitutional provision, which is normative and qualified as a nation's desirable concept that needs to be real to create a social contract. However, constitution in its dynamic meaning is associated with assumption which claims that constitution is not only juridicalnormative formulation, but constitution should be practical and also shows the interaction among the nation's components.

\footnotetext{
${ }^{1}$ Undang-Undang No. 10 tahun 2016 pasal 7.

${ }^{2}$ MB. Zubakrum Jenreng. 2016Pilkada Serentak Penguatan Demokrasi di Indonesia, Pustaka Kemang. Hal. 8

${ }^{3}$ MB. Zubakrum Tjenrung, Ibid. hal 8.

${ }^{4} \mathrm{MB}$. Zubakrum Tjenrung, Ibid. hal. 9.

${ }^{5}$ K.C. Dalam Modern Constitutions, (London Oxford University Press 1976), hal 3.
} 
${ }^{1}$ Thereby, constitution is interpreted as legal document and legal social-political document that has a special legal position and also categorized as supreme in a country's system, which consists of basic law related to a country's power principles, purposes or aims, authorized organization, function and authority, responsibility, limitation of authority, and also arrangement of relations among the higher institutions.

According to Albert Bilaustin, describing constitution's authority and characteristic in a country is called "The queen legal". It behaves as the highest law, which is strong, and cannot be defeated by other legal rules. By observing Blaustin's view, it can be derived that all Acts which are associated with general election of local leaders (PILKADA) should refer to the highest legal source, which is Pancasila and the 1945 Constitution of Republic of Indonesia. The regulations of the Acts which are associated with general election of local leaders are: Acts No: 22, 2014, Enactments of Government Regulation in Lieu of Law No: 1, 2014, Acts No: 1, 2015, Acts No: 8, 2015. Substantively, those regulations should be in accordance with Pancasila and the1945 Constitution of Republic of Indonesia. When all regulations which are mentioned above have contradiction with the spirit of the 1945 Constitution of Republic of Indonesia, they already betray the highest legal source of Indonesia, neglect and also desolate an order of the life of the unitary country and nation, Archipelago Insights as the National Platform. ${ }^{2}$

There are six basic concepts that have been building blocks for Indonesia's national insights. Those concepts are derived from the nation's treasures which are integrated as Indonesia's interest and also have become Indonesians' reference for the present and for the future. Those concepts are:

1. A concept to integrate the variety of nation's components, coalescence, and unity.

2. A concept to accumulate national power of nationality.

3. A concept to actualize the desire to live along with geopolitics.

4. A concept to actualize nation's sovereignty of its mother land.

5. A concept to make a country as struggling media to actualize the nation's dreams and archipelago.

6. A concept to maintain and defend the totality of national area.

In the concept of simultaneous general election of local leaders, the building blocks of Archipelagic Concept should be the visional base in the level of policy makers and in the level of democratic implementation trough simultaneous general election of local leaders. The implementation of simultaneous general election of local leaders should respect the nation's diversity, uphold the coalescence and unity, maintain the nationality, reflect nation's sovereignty as a whole, defend the nation's dream, and also maintain the wholeness of United Nation of Republic of Indonesia. By having Archipelagic Concept as visional base in implementing simultaneous general election, then every form of non- constitutional democracy implementations should be removed, as well as every form of intimidation, effort to divide nation's unity, primordialism, and also democratic manipulation that have been interpreted as depredator of national concept's building blocks.

National Defense as Conceptual Base. ${ }^{3}$

National defense as nation's dynamic condition is an output resultant from every national effort at particular moment to actualize national's purposes and dreams. Nation's problem can be solved by using eight approaches of national life. They are "astagatra" that consists of three natural aspects, which are geography, demography, natural resources, and also other five social aspects, which are: ideology, politic-economy, social-culture and also security defense. From the "astagatra" aspects above, each one has its integrity and also can be valued to track the level of current and future national defense condition. For knowing the national defense level, it is necessary to have qualitative and quantitative data that can be found on "astagatra" aspects. Then the data is obtained objectively and graded honestly to get national defense level that can be done due accountability.

The realization of Pancasila democracy is actually contains social insecurity whether it is derived vertically, or horizontally, and it can disturb the politic stability and national development. That is why it is crucial to have vigilant attitude and anticipation of every nation's component so that every kind of insecurity in general election could be minimized or even could be obliterated. The executor of democracy trough general election should deliver Indonesians to have better life and not the opposite where the life of united country and nation becomes worse.

\section{B. General Election according to the Acts No. 1, 2015 and No. 10, 2016}

General election of local leaders and their vices are implemented based on the Acts No. 10, 2016 related to second change of the Acts No. 1, 2015 regarding Enactment of Government Regulation in Lieu of Law No. 1, 2014 about the election of governor, regent, and mayor had become the Acts, chapter 1 verse (10) that states: General Election Supervisory Board which is abbreviated as (BAWASLU) in Bahasa, is an organizer institution of general election which is in charge to observe the implementation of general election in every scope of

${ }^{1}$ MB. Zubakrum Tjenrung, Opcil. Hal 10.

${ }^{2}$ Modul BIDANG Studi Geopolitik dan wawasan nusantara . Lembaga Ketahanan Nasional, PPSA XX, Tahun 2015. Dalam MB. Zubakhrum Jenreng, PILKADA SERENTAK Penguatan Demokrasi di Indonesia 2016, hal 11-12.

${ }^{3}$ Modul Bidang Studi Ibid. 13. 
Republic of Indonesia like has been mentioned in the Acts that arrange the implementation of general election and has authority in the observation of general election according to proper policies which are stated in the Acts.

Next, by referring to the regulations and the Acts of General Election Commissions or which is abbreviated as (KPU) in Bahasa and General Election Supervisory Board which is abbreviated as (BAWASLU), the regulations are: 1). The regulations of BAWASLU No. 14, 2016 related to the Integrated Law Enforcement Center on the election of governor and his/her vice, regent and his/her vice, and also mayor and his/her vice. 2). The regulations of BAWASLU No. 13, 2016 about the administration related to the prohibition to give or to pledge money or any other financial or material sources that have been done in systematic and massive structure in the election of governor and his/her vice, regent and his/her vice, and also mayor and his/her vice ${ }^{1}$

By the validation of Acts No. 1, 2015 and Acts No. 10, 2016 that explain about general election is a general election of local leaders, it strengthen people's sovereignty in the local regions that elect their leaders democratically. By discussing people's sovereignty, theoretically, it cannot be separated from theory of democracy especially in the assessment of people's sovereignty implementation in governmental system. ${ }^{2}$ Theory of democracy has become basic essence of people's sovereignty truth because the principle of democracy is derived from Greek words, "demos" and "cratain/kratos" which mean "people/citizens" and "govern." It is an essence of people's sovereignty. The truth of democracy aims to give freedom for every people, and they have opportunity to participate in decision making. The process of people's participation to manage the country has actually been existed since long time ago, but in democracy history, it was so hard to be implemented in a country. Readable phenomenon related to the appropriateness of people's right to participate in decision making directly in many countries are access able trough representative institutions. These institutions then claim to implement their decisions for the sake of people. In order to show the limitation of people's sovereignty in decision making, and also limited effectiveness on several parts of participation, the issues that need to be discussed are:

1. People's participation in momentum of democracy is mostly visible in the election of country leaders such as election of president, governor, regent, and mayor and also the lowest level of the hierarchy. This kind of participation is implemented through direct general election. ${ }^{3}$

2. People's participation in solving problems that have crucial impacts for the people such as referendum which is associated with the change of a country's constitution or referendum that has relation with an existence of a region in a country. A concrete example of referendum that had been experienced by Indonesia is the case when Indonesia freed the East Timor.

3. People's participation in the Acts making is associated with input and precious suggestions in formulating a regulation of Acts whether it is national, regional, or rural.

Rousseau in Munir Fuady argues that there is a strong relation between "participation" factor and "control" factor, where both of these factors are tied of freedom factor. Rousseau also extremely argues that a man can be forced to be free, and the so called freedom here can be meant an obedience of the law that has been decided by himself (obedience to law one prescribe to one self). ${ }^{4}$

Carole Pateman's statement that has been quoted by Munir Fuady states that "there is no one that could be a master of another person. When a person becomes a master of himself, then freedom means control of his life which is actually a requirement to proclaim that the person has become the master of himself. ${ }^{5}$ From several views above, the author derived a definition of participation. It is a form of people's involvement in deciding any policy of a country which is associated directly with people, although in some aspects, people are not involved directly in decision making on the form of the Acts. In operating country's implementation tasks, a country or government is not avoided from people's supervision or control as a democracy consequence. This is highly related to the classical slogan which states that government comes from people, by people, and for people. It means people are given observing limited function. There are numerous experts give predicate to the word "democracy" to show that to comprehend the meaning of democracy, it should be adjusted to conditional context. It means the development of democracy and the process to perceive it as governmental system will always be tied of space and time. In the space context, democracy is perceived as a governmental system that has been bound to factors of environment, social, politic, law, economy and culture (demography and geography). Meanwhile, the time context perceives democracy as a development in the history of human being's life. ${ }^{6}$ To have deeper understanding about this case, types of democracy will be mentioned below.

The appearance of slogans liberty, elegits, and fraternity strengthens the theory of social contract as

${ }^{1}$ Badan Pengawas Pemilihan Umum Malut 2016.

${ }^{2}$ H. Alwi Wahyudi 2012, Op. Cit. hal. 209.

${ }^{3}$ Munir Fuady, 2009, Konsep Negara Demokrasi, Refika Aditama, Bandung, hlm. 36. Diramu dari pemikirannya tentang Partisipasi Rakyat Dalam Negara Demokrasi, ia menjelaskan bahwa partisipasi masyarakat dalam Negara demokrasi tidak hanya pada pemilihan umum memilih wakil-wakil rakyat, melainkan juga keputusan-keputusan penting lainnya.

${ }^{4}$ Rousseau, didalam Munir Fuady, 2009, Konsep Negara Demokrasi, Refika Aditama, Bandung, hlm. 42.

${ }^{5}$ Carole Pateman, 1975, hlm. 27, Lihat didalam Munir Fuady, Ibid, hlm. 41.

${ }^{6}$ Firdaus, Pertanggungjawaban Presiden dalam Negara Hukum Demokrasi, Yrama Widya, Bandung, 2007, hlm. 30. 
foundation of the implementation of shared life to the necessary of managing the agreeable Acts where people respect each other and live in pactum unions. ${ }^{l}$ That is why a king has responsibility to respect the law and could be punished if he violates the law. Marsilius, in Firdaus, confirms that "people are the source of every power and government is a mandate of people." 2

Conceptually, the idea of constitutional democracy is being developed brom two ways of thinking in different phase since the idea of constitutional democracy was mentioned for the first time in 18th century and in the beginning of 19th century. It was well known as classical legal country (formal), while the development of constitutional democracy in 20th century was known as modern constitutional legal country (material). ${ }^{3}$ By the appearance of the idea of constitutional democracy, this caused implication to the authority limitation where in constitution, authority limitation which is based on democracy system had been implemented before. The idea of authority limitation is actualized and protected by constitution. ${ }^{4}$ It aims to avoid authority centralization or accumulation by organizing country.

The 1945 Constitution of Republic of Indonesia. ${ }^{5}$ General election is a democracy media to create governmental system that has people's sovereignty. Ideally, government of a country which is formed by its people should be implemented according to people's wish and for people's well-being. ${ }^{6}$ General election is implemented to elect people's representatives and other government officers who speak out about people's conscience and serve the people. General election is one of people's media to release its sovereignty, and because of this reason, general election should refer to principles of democracy. ${ }^{7}$ General election system is a series of regulation that arrange about:

1. How the voters express their own political preference; and

2. How the voters' votes are interpreted to be position.

In order to fulfill the task of interpreting votes to positions, the elements of general election technical system which are needed are:

1.The stance of candidate nomination,

2. The stance of voting,

3.The area of electoral region,

4.Scope of electoral region,

5. The stance of decision making. ${ }^{8}$

The development of national law, explicitly, reflect Indonesia's current situation where the social transformation process is heading to modernization that has been wrapped in legislation process regularly and continuously. Adopted philosophy in national law development for 30 years is a development of legal concept where the role of law is people's renewal media has not been changed yet. Substantively when we depart from the previous concept, we may conclude that legal reformation is an absolute step of main urgent task (sense of urgency) in organizing the nation's life to be more democratic, especially when political system transformation and state administration system that have been implied since the era of reformation are assumed as too fast. Therefore, the presence of law is highly necessary to secure the process of reformation mission, so that it will keep staying in constitutional corridor.

The amendment of 1945 Constitution of Republic of Indonesia on October 19, 1999 (1st amendment), August 18, 2000 (2nd amendment), November 19, 2001 (3rd amendment), August 10, 2002 (4th amendment) are implemented partially and as gradualist example of legal development that gives crucial impacts to the paradigm change of political life and state administration of Indonesia. The transition of authoritarian system to democratic system seems to be clearly visible when the result of 3rd amendment chapter 1 verse (2) states that "The sovereignty is on people's hands and needs to be done according to the 1945 Constitution of Republic of Indonesia. It decides to change the structure of People's Consultative Assembly as nation's highest institution to nation's institution that manages House of People's Representatives and Assembly at Province/Region. According to chapter 2 verse (1), "People's Consultative Assembly consists of Assemblies at Provinces/Regions which were elected trough general election and are arranged by the Acts". The members of People's Consultative Assembly are not some of certain group envoys who are appointed based on appointment, but are the members of House of People's Representatives and Assemblies at Provinces/Regions who are elected by

\footnotetext{
${ }^{1}$ W. Friedman, Legal Theory, New Yorka, 1960 dan telah diterjemahkan oleh Arifin, Teori dan Filsafat Hukm, Rajawali Press, Jakarta, 1990, hlm. 74, di dalam Firdaus, Ibid, hlm. 31.

${ }^{2}$ Ibid, didalam Firdaus, Ibid.

${ }^{3}$ Sri Soemantri, Op.Cit. hlm. 43. Di dalam Firdaus, Ibid.

${ }^{4}$ Ibid.

${ }^{5}$ Editor Citra Umbara, Undang-undang Republik Indonesia No. 12 Tahun 2003 tentang Pemilihan Anggota Dewan Perwakilan Rakyat,

Dewan Perwakilan Daerah dan Dewan Perwakilan Rakyat Daerah, Citra Umbara Bandung, 2003, Hlm. 3

${ }^{6}$ Merphin Panjaitan, Gerakan Warga Negara Menuju Demokrasi, Restu Agung, Jakarta, 2001, Hlm. 55

${ }^{7}$ Ibid

${ }^{8}$ Pipit R. Kartawidjaja dan Mulayana Kusumah, Sistem Pemilu Dalam Kosntitusi, KIPP Eropa, Jakarta, 2002 , Hlm. 155

${ }^{9}$ UUD 1945 pasal 1 layat 2, dan pasal 2 ayat 1
} 
people trough general election (chapter 2, verses 1 of the 1945 Constitution of Republic of Indonesia). This matter is being confirmed once again by Acts No. 22, 2003 related to Arrangement and Position of People's Consultative Assembly, House of People's Representatives, Regional Representative Council, and Assembly at Province/Region. The sovereignty consequence that was incarnated to superiority of People's Consultative Assembly should be given back to people and being implemented through 1945 Constitution of Republic of Indonesia.

General election systems are different from each other. It depends to what side that has been shown to people. Whether it is visible as a free individual who can decide his/her own choice, or people who are just being regarded as groups that have no right to decide their own representatives to have position in the legislatives, or even do not have right to nominate themselves as people's representatives. ${ }^{1}$ Based on the issues that have been mentioned above, general election can be divided into two types: ${ }^{2}$

a. Mechanical Selection System

Mechanical vision puts people as the same mass. Liberalism, socialism, and communism are all derived from mechanical vision. This vision prioritizes individual as a controller of active voting right and view people as individual masses who vocalize their vote in one voice in an election.

b. Organic Selection System

Organic vision puts people as numbers of individuals who live together in every kind of fellowship based on: geological aspect (household, family), particular function (finance, industry), other social layers (laborers, farmers, intellectuals) and other social institutions (such as university). In this vision, people are regarded as organisms that have organs, and these organs possess their own particular positions and functions for their totality like fellowships that have been mentioned above. Based on this vision, those fellowships of life are prioritized as the controllers of voting right. On the other hand, they are kind of right controllers to delegate their representatives as legislatives.

The Institute for Democracy and Electoral Assistance (IDEA) created a system classification for general election system like will be mentioned below: ${ }^{3}$

1. Majority System (Majoritarian/Plurality) is well known in Indonesia as District System;

2. Half Proportional System; and

3. Representative Proportional System which is well known in Indonesia as Proportional System.

Majority system (district) is when election is determined based on the majority votes of the general election. Theoretically, this system is divided into several types. They are:

1. First Past the Post (FPTP). It is when voters give their votes for a candidate and the candidate who gains most votes will win. This does not mean the candidate himself gets the majority of the votes.

2. Alternative Vote (AV). It is when voters give their preferences with the number that shows election priority like $1,2,3, \ldots$, for the candidate that has been nominated by each political party. For instance, there is a candidate $\mathrm{A}$ to candidate $\mathrm{E}$, then if candidate $\mathrm{C}$ has been the favorite of the voters, then the next number for the rest candidates should suitable with the voters' preference. If there is candidate who win $50 \%$ of the votes +1 vote (majority), then the votes from the least popular candidate should be distributed to candidate who has next number of the amount of voters' preference.

3. Two Rounds. In its implementation, it gives the chance if there is no candidate who gains $50 \%+1$ vote on the first round. The second round is implemented as the two candidates compete to gain the most votes. ${ }^{4}$

4. Bloc Vote and Party Block Vote. In this type, the voters can vote as many as the numbers of the candidates. If there are five candidates who need to be elected, every voter may choose till five candidates. Five candidates who win in every district (gain most votes) will be determined as winners. If four types above are the types which are used in a district who has singular candidate, the fifth type is a type which is mostly used in districts which have plural candidates, which is:

5. Multi Member District Plurality (MMDP). For this type, the voters give choices as many as available positions. If $n$ is position, then $n$ of candidate who gain the most votes would be elected. ${ }^{5}$

Representative Proportional System (proportional) is a system where every electoral region has several candidates that need to be elected and whether they will be elected or not, will be seen through the proportion (percentage) of support that have been given by their political parties in their own region. ${ }^{6}$ Theoretically,

\footnotetext{
${ }^{1}$ Moh. Kusnardi, dan Harmally Ibrahim, , Pengantar Hukum Tata Negara, Pusat Studi Hukum Tata Negara Fakultas Hukum UI dan CV Sinar Baakti, Jakarat, 1988, Hlm. 333

${ }^{2}$ Ibid, Hlm. 333-334

${ }^{3}$ Pipit R. Kartawidjaja dan Mulyana W. Kusumah, 151

${ }^{4}$ Andrew Elis, Melanjutkan Dialog Menuju Reformasi Konstitusi di Indonesia, International IDEA, Sweden, 2002, Hlm. 265

${ }^{5}$ http//.www.google.com.id/sistem pemilu, Tinjauan Singkat tentang Sistem Pemilu Yang Diusulkan Dalam Rancangan Amandemen Terhadap UU No. 3 Tahun 1999 tentang Pemilu, tanggal akses 03 November 2003, Hlm. 14

${ }^{6}$ Kevin Raymond Evans, Sejarah Pemilu \& partai Politik di Indonesia, PT Arise Consultancies, Jakarta, 2003, Hlm. 125
} 
Proportional System is divided into: ${ }^{1}$

1. List Proportional Representative. This system is divided into:

a. Proportional System with the System of Locked or Closed Lists, where constituents only have chances to elect the political party in general election, while the lists that determine legislative candidate who will represent the constituent will be determined in private by the party internally.

b. Proportional System with the System of Opened Lists where constituents are given freedom to elect the candidates that they perceive to be worthy to represent a party. In this system, political party that has been the participant of general election only needs to propose the legislative candidates' names whether it is just singular representative or several representatives.

c. Proportional System with the System of Free Lists. Constituent has freedom to elect more than one candidate from several political parties. In this system, there are the lists of the candidates' names which are arranged alphabetically from various political parties. The voters then write down the name lists according to their conscience.

2. Mixed Member Proportional (MMP). Voters get two different letters or one letter which is divided into two general election systems: The first one for the political party election (national), the other one for local candidates in their district (local). Then, it will be decided based on the proportion of RP. ${ }^{2}$

3. Single Transferable Vote (STV). The voters decide their choices according to preference lists. The first candidate who is able to reach the quota of the votes would be elected. The first candidate with the least preference will be dispelled and the votes that he/she gains will be distributed to the second popular candidate. This process will be repeated until the $n$ of the numbers of the candidates reaches the quota. ${ }^{3}$

Related to people's interest and government's intervention on the behalves that had been mentioned above". "Governance is interpretation of government then being improved and popular with the call Good Governance. ${ }^{5}$ Merin and Mayntz define Governance as: "Political Government in modern society is seen as control toward people, but it is started from the plurality of governmental implementation executants."

On the other hand, the term good governance is hardly to be found in Indonesian language in order to find appropriate interpretation. Giving standardized definition for that term is not an easy task. However as general, the term good governance could be understood as a good management system of a country and is also supported by three pillars, which are public governance, corporate governance, and civil society where the relations between these three and their rules should be derived from democratic agreement. ${ }^{6}$ UNDP states that the definition of Good Governance is "synergistic and constructive relation among the countries, private organization, and society. Derived from this definition, UNDP proposed characteristic of Good Governance, such as participation, legal supremacy, transparency, responsiveness, building consensus, equality, effectiveness and efficiency, being responsible and strategic vision. ${ }^{7}$ Meanwhile, J.B. Kristiadi argues that: Good Governance might be achieved through proper management between market function and organization function, including public organization, so that low budget transactions could be attained. ${ }^{8}$

Based on several descriptions above, it can be said that Good Governance is a solid, responsible, efficient, and effective governmental implementation by guarding the constructive interaction synergy domains such as: Country, Private Sector, and Society. The system turnover as the access that has been caused by amendment could be described as followed:

1. Before Amendment

Based on chapter 4 and 7 of Acts No. 3, 1999 related to general election, general election system is proportional system with closed/locked system for choosing the members of House of People's Representative, Assembly at Province/Region Level I and Level II. Meanwhile, the group's representative for regions could be held according to the appointment.

2. After Amendment

General election system that has been implemented and divided into two in accordance with the instruction of chapter 2, chapter 22E of the 1945 Constitution of Republic of Indonesia and then being concretized through chapter 6, verse 1 and 2 of Acts No. 12, 2003. First, general election for electing the members of House of People's Representatives and Assembly at Provinces/Regions are implemented with proportional system by using the opened system. Second, general election for electing the members of Regional Representative Council

${ }^{1}$ Pipit R. Kartawidjaja dan Mulyana W. Kusumah, op.cit, Hlm. 156-158

126 Ibid

${ }^{16} \mathrm{http}: / /$ www.google.com.id/sistem pemilu,op.cit, Hlm.11-12.

${ }^{4}$ Agung Djojosoekarto, Kapasitas Lembaga-lembaga Daerah Dalam Mewujudkan Good Governance Local, UNDP, ProgrammeOfficer Partnership, Focal Point, Jakarta, 2002, Hlm. 2

${ }^{5}$ Lembaga Administrasi Negara dan BPKP, Akuntabilitas dan Good Governance, Jakarta 2000, Hlm. 11

Hlm. 1

${ }^{6}$ Sekretariat Pengembangan Public Governance, Public Good Governance Sebuah Paparan Singkat, BAPPENAS, Jakarta, 2002.

${ }^{7}$ United Nations Development Program, op.cit. Hlm. 25.

${ }^{8}$ Ibid, Hlm. 39. 
will be implemented by using district system with the majority votes. Appointment System in the determination of People's Consultative Assembly members that had been implemented in 2004 will be invalid.

\section{Local Leader Election based on Pancasila.}

The implementation of local leader election is a section of overall democratic agenda actualization or a commitment of democratic country as instructed by Pancasila constitution. Democracy process in local area is expected to produce local leaders who reflect the paradigm of people's aspiration as the actual. Indonesia occupies the democracy firmly and tries hard to achieve it as what has been instructed by constitution, where the type of democracy which is highly respected is Pancasila democracy. One of Pancasila democracy practice is general election that becomes transition momentum whether it is in central or local area, values and philosophies of Pancasila equivalences which are associated with universal democracy principles especially developed freedom principles, justice and human rights enforcement. That is why the democracy which is implemented in Indonesia is Pancasila Democracy. It is a democracy that submits Pancasila principles as the foundation of the country and nation's life. ${ }^{1}$ Pancasila a unity value that cannot be separated from its each principle, and the arrangement of principles, cannot be reversed. Although every principle contains the values of diversity, but all of them are systematic unity which is started from 1). Believe in the One and Only God, 2). Fair and Civilized Humanity, 3). The Unity of Indonesia, 4). Democracy Led by Wisdom of Deliberations among Representatives, 5). Social Justice for the whole Indonesians. These all had been completed by the content of precepts that describe the integrity of Pancasila.

By being collective consensus, we are as sovereign nation and country should obey Pancasila as Ideal Foundation, : ${ }^{2}$ As a view of life, Pancasila contains knowledge about the essence, origin, purpose and the meaning of the whole universe, especially human beings and their life, whether it is individually or socially. The nation's philosophy of life reflects as a whole by assigning the prestige and dignity of human beings as central factor in living as good nations and having Pancasila is the essence of life and also becomes basic measurement of every nation's pre-life. In other words, Pancasila is morality dreams of Indonesians which tie all people as individual or as united nation.

Pancasila has been recognized as philosophy, ideology, and nation's foundation. As the foundation of united nation and country, Pancasila is Ideal foundation for the implementation of general election in the national as well as in the local regions. MB. Zubakrum Tjenrang states that "the values and philosophies of Pancasila Equivalence or as associated with universal democracy principles are the continuous freedom principles and also justice and human rights enforcement. Thus, democracy that has been implemented in Indonesia is Pancasila democracy, which is democracy that has been concordant to the values of Pancasila as the foundation of nation's view of life." 3

${ }^{4}$ Sapno (2009) states that "general election which implements the values of Pancasila should be interpreted as the actualization of democracy maturity without badgering the values of democracy and it is not appropriate to provoke the conflict that may disagreement. Basically, democracy in Indonesia should be connected to the values of Pancasila as an Ideology in Bhineka Tunggal Ika related to living in harmony as a unitary nation. One key to create a moderate society in politics like holding local leaders election is to comprehend fully the values of Pancasila and Bhinneka Tunggal Ika for Indonesia. The implementation of Bhinneka Tunggal Ika and the values of Pancasila in general election aims to actualize the life of people who get along well, in secure, in peace and respect each other in the form of nation' unity and should be synchronized with the values of Pancasila for the peace of nation and country. (Sapno 209/20)

Pancasila in general election can be interpreted in simple daily life, such as cooperate together, being tolerant, respect each other, and appreciate each other including respecting the different preference in supporting different candidates of governor, regent, and mayor in general election. Appreciating and respecting others' opinion in general election is the implementation of the values of Pancasila including the attitude that shows unity value of united nation to actualize the peace as one aspect of Pancasila that has been longed together. (Simardjo144/23)

Actually, general election is democracy party that should be associated with principles of Pancasila and does not contradict with its each principle which is related to each other and also prioritizes the values of Bhinneka Tunggal Ika for all Indonesians without any exception. Because by making Pancasila which is associated with Bhinneka Tunggal Ika as the priority, it will cause high value of nationalism, brotherhood, and unity among the nations, without differentiate the race, tribe, religion or ethnicity. (Simardjo144/23)

In general, Pancasila is a foundation and ideology for Indonesia. Therefore, Pancasila can be accepted by

${ }^{1}$ Tim Visi Yustisia UUD 1945 Republik Indonesia Kabitne Kerja Jokowi Jeka, hal 2.

${ }^{2}$ MB. Zubakrum Jenreng. 2016Pilkada Serentak Penguatan Demokrasi di Indonesia, Pustaka Kemang. Hal. 8

${ }^{3} \mathrm{MB}$. Zubakrum Tjenrung, Ibid. hal 8.

${ }^{4}$ Dedetugas.blogspot.co.id tanggal 30 Oktober 2016

${ }^{5}$ Dedetugas.blogspot.c.id. ibid 
all Indonesians and has been foundation and also guidelines of governmental implementation of the Republic of Indonesia as well as the general election, should fit the values of Pancasila so that it will take place safely and being respective to every regulation of the content and orientation of Pancasila. (Simardjo144/21)

\section{Analysis.}

The Implementation of Direct and Indirect General Election of Local Leaders.

General election of local leaders and their vices are implemented based the Acts No 10, 2016 related to the second change of the Acts No. 1, 2015 regarding the Enactment of Government Regulation in Lieu of Law No. 1, 2014 about the election of government, regent, and mayor has become the Acts, chapter 10 verse (10) states that: General Elections Commission in the implementation of general election should: a). treat the candidates of regent and the vice regent equally; b). convey information of general election implementation to the society; b1. implement the recommendation nor the decision of Election Supervisory Agency about the sanctions of general election administration immediately; c). implement the decision of Election Organizer Ethics Council; and d). implement other responsibilities which are appropriate with the provision of legislation. Next, all activities will be implemented based on the regulation of General Elections Commission.

The implementation of general election of local leaders and their vices should refer to the legal foundation of the 1945 Constitution of Republic of Indonesia. In this case, chapter 18 verse (4), which is stated; (governors, regents, and mayors respectively as the heads of governments in the provinces, regencies, and cities are democratically elected), chapter 20, (1), (2), (3), (4) and (5), chapter 21, chapter 22 (2), chapter 27 verse (11) and chapter 28D verse (3) the 1945 Constitution of Republic of Indonesia. As for the legal foundation of general implementation has been managed by distributing regulation which are already complete, however in every general election of local leaders, violations on the constitution or on the Acts often happen. In this study, the author found the data of general election violation in 2014 due to the report of general election of local leaders in North Maluku in 2014. The general elections are included election of governor, regents, and the mayors. There are four samples of different regencies and cities. They are: 1 ). There were 12 violation cases happened in North Halmahera Regency, 2). There were 8 violation cases happened in South Halmahera Regency, 3). There were 17 violation cases happened in the city of Ternate, 4). There were 29 violation cases happened in the city of Tidore, while the general election of governor in 2014, violation happened in the process of counting the votes and caused 6 candidates required some polling stations to redo the general election. However, after the result came and there was one pair of candidates won the majority of the votes, the rest 5 pairs of the candidates sued the pair of candidate who already won. This case showed that every candidate and every citizen who participated in general election might be risky and was not suitable with the constitution. General election will not be implemented democratically if the organizers of general election neglect the Pancasila and the 1945 Constitution of Republic of Indonesia. That is why general election of local leaders and their vices is better to be handled by local government in order to implement election system of local leaders and their vices which are suitable with the region's condition and circumstances in accordance with the spirit of regional autonomy.

The consistence of general election of local leaders and their vices should be guaranteed by General Elections Commission, Election Supervisory Agency, and Local Governments in the form of responsibility. Without responsibility, the election result could be cancelled anytime and will be processed according to the applicable law if there is violation or criminal act without waiting the problem to be protracted in Constitutional Court, because the violation of general election regulation is categorized as criminal act. In order to support the related issue, it is necessary to have special Acts related to "the settlement of general election crime" where the settlement should be directly implemented in the Court according to the local or regional autonomy and cost savings.

Based on the study which was derived from the case in North Maluku, general election of local leaders and their vices still neglects the principles of generality, specialty, freedom, honesty, and justice. It is necessary for that area to conduct indirect election because the reports showed that any violation regarding general election implementation is still in practice. It could be seen from the reports that have been obtained from 5 (five) regions. They are the province of North Maluku, the regent of North Halmahera, the regent of South Halmahera, the city of Ternate and the city of Tidore Islands. General elections that have been implemented in these areas were full of dishonesty and violation that have been committed by General Election Commission, Election Supervisory Agency, and Local Government. Because of these reasons, it is crucial to publish Government Regulation which is specialized for deciding the indirect election in North Maluku and other regions where the implementation of honesty, justice and legal certainty are highly required.

\section{E. Conclusion}

1. General election of local leaders and their vices are generally connected to Pancasila and the 1945 Constitution of Republic of Indonesia which are ideal and constitutional. The violation of general election of local leaders and their vices especially in the system of direct general election should be associated with 
Pancasila democracy and legality principles. This is highly linked to its legal principles and requirements based on the system of direct election of local leaders and their vices. Every type of neglect of Ideal Foundation and constitution that has been found had been implemented, although it has been conducted directly, would be called invalid.

2. The consistence of the implementation of general election of local leaders and their vices which is associated with Pancasila and 1945 Constitution of Republic of Indonesia should be guaranteed by the election executors such as General Election Commission, Election Supervisory Agency, and Local Governments. The result of this study shows that there is still no consistence of Ideal Foundation and Constitution on the implementation of direct general election of local leaders and their vices. Because there are still many people doubt the implementation of direct general election due to the controversy of general election of local leaders, although the general election has been implemented directly but still neglect the values of Pancasila democracy and constitution. That is why the so called direct general election is categorized as invalid or even illegal.

3. The direct general election of local leaders and their vices neglects the principles of specialty, generality, freedom, secret, justice, and honesty. In fact, direct general election cannot guarantee the principles of democracy and its legality based on Pancasila and the 1945 Constitution of Republic of Indonesia, if the implementation of general election is implemented in dishonesty and violated the regulation. The report that has been obtained from North Maluku showed that direct general election has potentials to be violated by some of General Election Commission, Election Supervisory Agency, and Local Governments who obscure the values of honesty and justice of Pancasila and the 1945 Constitution of Republic of Indonesia.

\section{REFERENCES}

Abdurrahman, 1987. Beberapa Pemikiran Tentang Otonomi Daearh, PT. Media Sarana Press, Jakarta.

Ahmad All, 2009. Menguak Teori Hukum (Legal Theory) dan Teori Peradilan (Judicialprudence) Kencana Pranada Media group, Jakarta.

Affan Gaffar, 1985. Politik Indonesia: Transisi Menuju Demokrasi, Pustaka Pelajar, Yogyakarta.

Agus Dwiyanto, dkk., 2002. Reformasi Birokrasi Publik di Indonesia, Pusat Studi Kependudukan dan Kebijakan Universitas Gajah Math, Yogyakarta

Amrah Muslimin, 1078. Aspek-aspek Hukum Otonomi Daearah, Alumni Bandung.

Ateng Syaripudidin, 1982. Memantapkan Pemerintah yang Bersih dan Berwibawa, Tarsito Bandung.

Bachsan Mustafa, 1979. Pokok-pokok Hukum Administrasi Negara, Alumni, Bandung

Sahran Basah. 1989. Perlindungan Hukum Terhadap Sikap Tindak Administrasi Negara, Bandung Unpat.

Dablan Taib. 2000. Kedaulatan Rakyat Negara Hukum dan Konstitusi, Liberty Yogyakarta.

A.V. Decey. 1971. Introduction to The Study of the Constitution, London: English Bociety.

Badudu J.S, Sultan Muhammad Zain, 2001. Kamus Umum Bahasa Indonesia, Pustaka Sinar Harapan, Jakarta. Bagir Manan, 1993. Hubungan Antara Pusat Dan Daerah Menurut UUI) 1945, Pustaka Sinar Harapan, Jakarta. Bruggink, J.J., 1999. Refleksi Tentang Hukum, Alih Bahasa Arief Sidharta, PT. Citra Aditya Bakti, Bandung. Candler Ralph C. and Plano Jack C, 1982. The Public Administration Dictionary, John willey \& Sons, Singapura. Cohen, john M. and Stephen B. Peterson, 1999. Administrative Decentralization, Strategies For Developing Countries Connection. Kumarian Press.

Darwin Muhadjir, 1996. Dalam Demokrasi Indonesia Kontemporer, Editor Riza Noer Arfani, PT. Raja Grafindo Persada, Jakarta.

Soehino. 2002. Perkembangan Pemerintahan di Daearah,Liberty Yogyakarta.

Sachruddin 2004-2009. Pembangunan Otonomi Daerah Memperkuat NKRI Catatan Seorang Auggota DPR RI, Serat Alam Media. Jakarta.

Dicey A.V. 2007, Introduction to Study of The Law of The Constitution (Pengantar Studi Hukum Konstitusi), diterjemahkan oleh Nurhadi, Nusa Media, Jakarta

Dasril Radjab, 2005. Hukum Tata Negara Edisi Revisa, Reneka Cipta, Jakarta.

Ellydar Chaidir, 2001. Hubungan Tata Kerja Presiden dan Wakil Presiden, Perspektif Konstitusi, Ull Press, Yogyakarta.

Francis Fukuyama, 2005. Memperkuat Negara (Tata Pemerintahan dan Tata Dunia Abad 21), Gramedia Pustaka Utama, Jakarta.

Friedman W., 1971. State and Rule of Law in Mixed Economy, Steven \& Son, London.

Hwlari Nawawi, 1984. Pengawasan Melekat di Lingkungan Aparatur Pemerintahan, Erlangga, Jakarta.

H.Moh. Alifuddin, 2012 Demokrasi Panduan Praktis Perilaku Demokrasi. MagnasCriptPublishing, Jakarta.

H. Rozali Abdullah, 2011. Pelaksanaan Otonomi Luas, dengan Pemilihan Kepala Daerah secara langsung. Rajawali Pers, Jambi.

H. Zainal Askin, 2012. Pengantar Tata Hukum Indonesia. Rajawali Pers,Mataram.

H. Inul Kencana Syaflie, 2011 Sistem Pemerintahan Indonesia. Reneka Cipta, Jakarta 
Putera Astomo, 2014 Hukum Tata Negara, Teori dan Praktek, Thofa Media Yagjakarta.

Heru Widodo, 2015 Hukum Acara Perse;isihan Hasil Pelkada Serentak di Mahkamah Konstitusi, Sinar Grafika. Jakarta Timur.

Bachtiar, 2015 Problematika Implementasi Putusan Mahkamah Konstitusi Pada Pengujian Terhadap UUD Raih Asa Sukses Jakarta.

Rahmat Rollyzon MZ, Sri Sundari, 2015 Pilkada Penuh Euforia, Miskin Makna, Berstari (anggota IKAPI) Jakrta.

Rizky Ariestandi Irmansyah 2013 Hukum Hak Asasi Mnusia dan Demokrasi Graha Ilmu, Yogyakarta

Jawahir Thontowi, 2016 Pancasila dalam Perspektif Hukum Pandangan Terhadap Ancaman "The Lost Generation" UII Pres Yogyakarta.

Sobirim Malian, 2001, Gagasan Perlunya Konstitusi Baru Penggganti UUD 1945. UH Press Jogjakarta.

H.Alwi Wahyudi, Hukum Tata Negara Indonesia Dalam Perspektif Pancasial Panca Reformasi, 2012, Pustaka Pelajar Madium.

Jimly Asshiddigie, 2005. Konstitusi dan Konstitusialisme di Indonesia, Konstitusi Press, Jakarta.

, 2006 Pengantar llniu Tata Negara, Konstitusi Press, Jakarta.

Josef Riwu Kaho, 1997. Prospek Otonomi Daerah di Negara Republik Indonesia, Rajawali Press, Jakarta.

Juanda, 2004, Hukum Pemerintahan Daerah ; Pasang Surut Hubungan Kewenangan Antara DPRD \& Kepala Kaerah, Alumni Bandung.

Mahiud M.D., 1999, Hukum dan pilar-pilar demokrasi, Gama media, Jakarta.

Moh. Mahfud M.D., 2010, Perdebatan Hukum Tata Negara Pasca Amandemen Konstitusi, Raj awali Pers, Jakarta

Moh. Mahfud M.D., 2009. Politik Hukum di Indonesia Edisi Revisi, Rajawali Pres, Jakarta.

Miriam Budihardjo, 1992. Dasar-Dasar Ilmu Politik, Gramedia, Jakarta.

Mustamin DM, dkk, 1999. Mandat, Delegasi, Attribusi dan Implementasinya di Indonesia Ull Press, Yogyakarta.

Rijass Rasyid, 1998, Desentralisasi Dalam Menunjang Pembangunan Daerah Dalam Pembangunan administrasi Indonesia.Pustaka, LP3ES, Jakarta.

Rita Triana Budiarti, 2010. On Record, Mahfud MD di Balik Putusan Mahkamah Konstitusi, Murai Kencana, Jakarta.

Sarundayag, 2002. Pemerintahan Daerah di Berbagai Negara, Pustaka Sinar Harapan, Jakarta.

Soerjono Soekanto, 1986. Pengantar Penelitian Hukum, UII Press, Yogyakarta.

Theo Hujibers OSC, 1982. Filsafat Hukum Dalam Lintasan Sejarah, Yayasan Kanisius, Yogyakarta.

Titi Triwulan Tutik, 2008. Pokok-Pokok Hukum Tata Negara Indonesia, Pasca Amandemen LJUD 1945.Cerdas Pustaka Publusher, Jakarta.

Ni'matul Huda 2008. UUD 1945 dan Gagasan Amandement Ualang, Rajawali Pres, Yogyakarta

2005, Hukum Tata Negara di Indonesia, Rajawali Pers Yogjakarta

Wahyudi Komorotomo, 2005. Mewujudkan Good Covernance Melalui Pelayanan Publik, Gajah Mada University Press, Yogyakarta.

O.0 Kaligis \& Associantes, 2006. Mahkamah Agung VS Komisi Yudisial di Malikamah Konstitusi, Revormasi Pengawasan Hakim,Perpustakaan Nasional Indonesia Jakarta.

Peraturan Perundang-undangan :

Undang-Undang Dasar Negara Repoblik Indaonesia (UUD) Tahun 1945.

(Sebelum Amandement).

Undang-Undang Dasar Negara Repuplik Indonesia 1945 dan (Amandemen dan Kabinet Kerja).

Undang-Undang Nomor 8 Tahun 2015 Tentang Pemilihan Kepalah Daerah (Pilkada)

Undang-Undang No: 12 Tahun 2008 Tentang Pemerintahan Daerah.

Undang-Undang No: 8 Tahun 2012 Tentang Pemilihan Umum Anggota DPR, anggota DPD, dan anggota DPRD. Undang-Undang No : 2 Tahun 2011 Tentang Perubahan atas Undang-Undang

No : 2 Tahun 2008 Tentang Partai Politik.

Undang-Undang No: 17 Tahun 2014 Tentang MPR, DPR, DPD dan DPRD (MD3).

Undang-Undang Nomor 23 Tahun 2014 tentang Pemerintahan Daerah Fukusmedia Bandung.

Udang-Undang No : 28 Tahun 1999 Tentang Penyelenggaraan Pemerintahan Yang Bersih dan Bebas dari Kolusi dan Nepotisme. Arkora Surabaya Indonesia.

Undang-Undang Otonomi Daerah Tahun 2000. Arkolah Surabaya Indonesia.

Undang-Undang No : 32 tahun 2004 Tentang Pemerintahan Daerah (UU lama).

Peraturan Pemerintah Pengganti Undang-Undang (PERPPU) Nomor 1 Tahun 2014 tentang Pemilihan Gubernur, Bupati dan Wlikota.

Undang-Undang Otonomi Daerah 2004 Terdiri :

Undang-Undang Republik Indonesia No 32 Tahun 2004 Tentang Pemerintahan Daerah. Karina Surabaya.

Undang-Undang Otonami Daerah 2006 Edisi lengkap. Fokusmedia

Undang-Undang Nomor 22 Tahun 2014 Tentang Pemilihan Gubernur, Bupati dan Walikota. 
Undang-Undang Otonomi Daerah tahun 2006

PERPPU Nomor 1 Tahun 2014 tentang Perubahan atas Undang-Undang Nomor 23 Tahun 2014 tentang Pemerintahan Daerah.

Peraturan Pemerintah (PP) Nomor 25 Tahun 2000 Yenyang Kewenangan Pemerinyah dan Kewenangan Propinsi Sebagai Daerah Otonomi.

Undang-Undang Nomor 1 Tahun 2015 Tentang Penerapan Peraturan Pemerintah Penggati Undang-Undang Nomor 1 Tahun 2014 Tentang Pemilihan Gubernur,Bupati dan Walikota

Undang-Undang Nomor 10 Tsgun 2016 Tentang Perubahan Kedua atas Undang-Undang Nomor 1 tahun 2015 Tentang Penetapan Peraturan Pemerintah Pengganti Undang-Undang Nomor 1 tahun 2014 Tentang Pemelihan Gubernur, Bupati dan Walikota menjadi Undang-Undang.

Peraturan Pemerintah No : 79 Tahun 2005Tentang Pembinaan dan Pengawasan atas Penyelenggaraan Pemerintahan Daerah.

Peraturan Pemerintah No : 38 Tahun 2007 Tentang Pembagian Urusan Pemerintahan antar Pemerintah Daerah, Pemerintah Daerah Propinsi dan Pemerintah Daerah

Jurnal pamon Praja, edisi 2009. Forum komunikasi alumni institute ilmu pemerintahan Jakarta.

Peraturan Pemerintah No: 19 Tahun 2010 tentang Tata cara Pelaksana Tugas dan Wewenang Serta Kedudukan Keuangan Gubemur sebagai Pemerintahan di Wilayah Propinsi.

http://www. landasan teori.com/2O15/09/teor/*-negara hukum-Pancasila-rule of law hal 1. 